\title{
Is Serum TWEAK a Useful Biomarker of Neuropsychiatric Systemic Lupus Erythematosus?
}

\author{
Veronika BALAJKOVA ${ }^{\mathbf{1}}$, Marta OLEJAROVA ${ }^{\mathbf{1}}$, Radka MORAVCOVA ${ }^{\mathbf{1}}$, \\ Petr KOZELEK ${ }^{2}$, Marie POSMUROVA ${ }^{2}$, Hana HULEJOVA ${ }^{1}$, Ladislav SENOLT ${ }^{1}$ \\ ${ }^{1}$ Department of Rheumatology, First Faculty of Medicine Charles University, Prague, Czech \\ Republic, ${ }^{2}$ Psychiatric Clinic, First Faculty of Medicine, Charles University, Prague, Czech \\ Republic
}

Received September 14, 2019

Accepted January 7, 2020

Epub Ahead of Print March 23, 2020

\begin{abstract}
Summary
The aim of this study was to determine the role of the tumor necrosis factor like weak inducer of apoptosis (TWEAK) as a serum biomarker of neuropsychiatric involvement in systemic lupus erythematosus (NPSLE). Levels of TWEAK levels were measured in sera of 92 patients with systemic lupus erythematosus (SLE), including 28 patients with neuropsychiatric lupus, and in 59 healthy controls using ELISA. All SLE patients underwent rheumatological, neurological and psychiatric assessments. We found no significant differences in TWEAK levels, between SLE patients and the healthy controls $(p=0.2411)$. Similarly, no difference was observed between the subgroup of NPSLE and healthy controls $(p=0.7658)$. The mean SLE disease activity (SLEDAI) was 13.25. No correlations between TWEAK levels with disease activity (SLEDAI, $r=0.2113$, $\mathrm{p}=0.2805$ ) or the most common NPSLE manifestations such as headache $(r=0.2079)$, seizures $(r=0.1101)$, cerebrovascular disease $(r=-0.2347)$, cognitive dysfunction $(r=0.1597)$ and anxiety ( $r=0.1397)$ were observed. Our data do not support the use of serum TWEAK as a discriminating biomarker for NPSLE. The role of the TWEAK in NPSLE remains to be investigated.
\end{abstract}

\section{Key words}

TWEAK • NPSLE • Systemic lupus erythematosus • Neuropsychiatric lupus

\section{Corresponding author}

Veronika Balajkova, Institute of Rheumatology, Na Slupi 4, 12850 Prague 2, Czech Republic. E-mail: balajkova@revma.cz

\section{Introduction}

The systemic lupus erythematosus (SLE) is a chronic multiorgan autoimmune disease with a broad spectrum of clinical manifestations, affecting particularly women of child-bearing age (Frieri 2013). Neuropsychiatric manifestations include a heterogenous variety of neurological and psychiatric syndromes involving the central, peripheral and autonomic nervous system (Bortoluzzi et al. 2015, Magro-Checa, Zirkzee, Huizinga, and Steup-Beekman, 2016). The prevalence of neuropsychiatric systemic lupus erythematosus (NPSLE) differs significantly among studies and ranges from $11 \%$ to $95 \%$ of SLE patients (Bortoluzzi et al. 2015, Hanly et al. 2010, Joseph and Scolding 2010, Kasama et al. 2016, Sibbitt et al. 2002). This broad span of the prevalence of NPSLE depends largely on the use of a different diagnostic and classification criteria, differences in cohort characteristics that may represent important confounders (e.g., age, ethnicity, gender), period of observation, and sometimes, by different clinical focus of clinicians (Perricone et al. 2015, Sarbu et al. 2015). Importantly, NPSLE is associated with increased morbidity and mortality and has a tremendously negative impact on the health-related quality-of-life of these patients (Hanly et al. 2010, Yazdany 2011).

In 1999, the American College of Rheumatology (ACR) developed nomenclature and definitions of 19 neuropsychiatric manifestations associated with SLE. ("The American College of Rheumatology nomenclature and case definitions for neuropsychiatric lupus syndromes," 1999). The most common presentations of NPSLE include headache, cognitive dysfunction, cerebrovascular disease, seizures and mood disorders (Bortoluzzi et al. 2015, Hanly et al. 2004, Jeong et al. 2015, Pamfil et al. 2015, Popescu and Kao 2011, Sarbu

PHYSIOLOGICAL RESEARCH • ISSN 1802-9973 (online) 
et al. 2015). Despite the ACR criteria, there is no unified diagnostic test sensitive or specific enough for NPSLE. Therefore, assessment of NPSLE still remains a clinical challenge and the diagnosis is based on physical examination, neuroimaging methods (MRI), psychiatric and neuropsychological tests and immunological tests.

The pathogenesis of NPSLE is multifactorial and not completely understood. There are two main pathophysiological mechanisms involved in the formation of a neuropsychiatric disability (Hanly 2014, Zirkzee et al. 2012): Inflammatory mechanisms characterized by the presence of autoantibodies, inflammatory mediators (tumor necrosis factor, cytokines, or immune complex deposits) and noninflammatory mechanisms including thrombotic or ischemic mechanisms (antiphospholipid antibodies, complement activation) (Belmont et al. 1996, MagroCheca et al. 2016).

A variety of autoantibodies play a significant role in the pathogenesis of NPSLE and their detection may support the diagnosis of NPSLE. Anti- ribosomal $\mathrm{P}$ protein antibodies, were significantly associated with psychiatric disorders, especially psychosis and depression (Briani et al. 2009, Isshi and Hirohata 1998). Some studies described the association between the antineuronal antibody (anti-NA) and psychosis (Kang et al. 2008, Wilson et al. 1979). Anti-phospholipid antibodies, particularly anti-cardiolipin antibodies have been reported in cognitive dysfunction and in reduction of psychomotor speed in SLE patients (Menon et al. 1999). Anti-NR-2 antibodies directed against NR2a and NR2b subtypes of the N-methyl-D-aspartate (NMDA) receptor are being investigated for cognitive dysfunction. (Kozora et al. 2008). Elevated levels of anti-NR-2 antibodies in cerebrospinal fluid in patients with diffuse NPSLE were observed, whereas there were no differences in serum anti-NR2 levels between NPSLE and healthy groups (Arinuma et al. 2008). The recent study shows the same association of antibodies to the NR1 subunit of NMDA receptors with NPSLE (Ogawa et al. 2016). One of the inflammatory mediators that contribute to cognitive dysfunction by disruption of the blood-brain barrier is metalloproteinase 9 (MMP-9) (Kozora et al. 2008).

Tumor necrosis factor-like weak inducer of apoptosis (TWEAK) plays an important role in the pathogenesis of SLE. TWEAK, a member of tumor necrosis factor superfamily, is a multifunctional, pleiotropic and proinflammatory cytokine, which is synthesized as a type II transmembrane protein (Bertin et al. 2013). Through the activation of its receptor fibroblast growth factor-inducible molecule 14 (Fn14), TWEAK regulates multiple cellular functions such as cell differentiation, proliferation, migration, angiogenesis, apoptosis or induction of inflammatory cytokines and chemokines (Winkles 2008, Xu et al. 2016). In addition, it has been demonstrated that TWEAK is significantly increased in urine and correlate with renal disease activity of patients with lupus nephritis (Liu et al. 2011, RuizOrtega et al. 2014, Xuejing et al. 2012).

There are several studies reporting that in animal models TWEAK/Fn14 pathway causes disruption of the blood-brain barrier (Wen et al. 2015). In animal models, MRL/lpr Fn14 wild type had impaired cognition increased immobility (depression-like behavior) in comparison to Fn14 knockout mice (Polavarapu et al. 2005, Wen et al. 2013, Winkles, 2008).

Based on these data, we aimed to determine the levels of serum TWEAK in patients with SLE, NPSLE and healthy controls to explore the value of serum TWEAK as a biomarker for neuropsychiatric lupus.

\section{Methods}

\section{Patients}

Patients fulfilling the revised ACR classification criteria for the diagnosis of SLE (Font and Cervera 1993) were recruited from the outpatient and inpatient clinic at the Institute of Rheumatology, Prague. Age- and sexmatched healthy controls were included. A signed consent form was obtained from each subject prior to initiation of the study. All patients were examined by experienced rheumatologists, neurologists, psychiatrists, and clinical psychologist. SLE activity was assessed by the Systemic Lupus Erythematosus Disease Activity Index (SLEDAI). Patients were classified as inactive if the SLEDAI score was $<4$. Patients with low active disease had SLEDAI score $\geq 5<10$. Active disease was characterized as SLEDAI score $\geq 10$. After exclusion of the other causes (neuroinfections, tumors, etc.), the diagnosis of NPSLE was based on neuropsychiatric symptoms, serological tests and brain MRI abnormalities according to the ACR nomenclature ("The American College of Rheumatology nomenclature and case definitions for neuropsychiatric lupus syndromes," 1999).

\section{Laboratory analysis}

Blood samples were collected from all SLE patients and healthy controls and were immediately 
centrifuged at $3500 \mathrm{~g}$ for $10 \mathrm{~min}$ and stored at $-80{ }^{\circ} \mathrm{C}$ until analysis. The values of $\mathrm{C} 3, \mathrm{C} 4$ complement components were detected by immunoturbidimetric assays and the antidsDNA levels by immunofluorescence technique. The levels of TWEAK were measured by commercially available ELISA (RayBiotech, Inc., Norcross, USA) according to the manufacturers' instructions. Absorbance was detected using the Sunrise ELISA reader (Tecan Group Ltd., Salzburg, Austria) with $450 \mathrm{~nm}$ as the primary wavelength. Interassay and intraassay reliability of the Tweak ELISA were CV $<10 \%$ and $<12 \%$ respectively. The minimum detectable concentration of TWEAK was $40 \mathrm{pg} / \mathrm{ml}$.

\section{Blood-brain barrier evaluation}

The function of the blood-brain barrier was evaluated by magnetic resonance on the T1 weight image after intravenous gadolinium application. If the native and post-contrast image was the same, then we assessed the barrier as unimpaired.

\section{Statistical analysis}

TWEAK levels were presented as median $( \pm \mathrm{SD})$. The distribution of data was verified by D'Agostino and Pearson omnibus and the Shapiro-Wilk normality test and Mann-Whitney $U$ test was used.
A $p$ value $<0.05$ was considered statistically significant. The correlation coefficients (r) were calculated using Pearson's correlation. All statistical analyses were performed using GraphPad Prism software.

\section{Results}

Ninety-two patients with SLE and 53 age- and sex-adjusted healthy controls were enrolled into this study. Demographics and clinical characteristics of the patients and healthy controls are shown in Table 1.

Neuropsychiatric manifestation occurred in 28 SLE patients $(25.76 \%)$ meeting the 1999 ACR criteria. SLEDAI score of the NPSLE patients was significantly higher than in remaining SLE patients (13.3 \pm 9.16 vs. $5.55 \pm 4.74, \mathrm{p}<0.001)$. The NPSLE group contained 14 patients with a high SLEDAI score and 7 patients with low disease activity.

The levels of TWEAK in sera were comparable between patients with SLE and healthy controls ( $2554 \pm 695$ vs. $2366 \pm 750 \mathrm{pg} / \mathrm{ml}, \mathrm{p}=0.241)$. In addition, the levels of TWEAK did not differ in patients with NPSLE compared to either SLE patients without neuropsychiatric involvement or healthy controls $(2425$ vs. 2554 vs. $2366 \mathrm{pg} / \mathrm{ml}$ respectively, $\mathrm{p}=0.7658$, $\mathrm{p}=0.5922)$ (Fig. 1).

Table 1. Demographics and clinical characteristics and characteristics of SLE patients, NPSLE subgroup and healthy controls.

\begin{tabular}{|c|c|c|c|}
\hline & SLE, $n=64$ & NPSLE, $n=28$ & Healthy Controls, $n=53$ \\
\hline$A g e^{a}$ & $41.62 \pm 13.25$ & $44.92 \pm 13.80$ & $45 \pm 14.17$ \\
\hline Female/male & $58 / 6$ & $26 / 2$ & $44 / 9$ \\
\hline SLE disease duration (years) ${ }^{a}$ & $3.93 \pm 10.03$ & $1.92 \pm 2.96$ & \\
\hline \multicolumn{4}{|l|}{ Cumulative disease involvement } \\
\hline Neuropsychiatric & 0 & 28 & \\
\hline Cutaneous & $41(64.06 \%)$ & $19(67.85 \%)$ & \\
\hline Renal & $34(53.12 \%)$ & $10(35.71 \%)$ & \\
\hline Articular & $56(87.5 \%)$ & $25(89.28 \%)$ & \\
\hline Hematologic & $52(81.25 \%)$ & $22(78.57 \%)$ & \\
\hline Serositis & $24(37.5 \%)$ & $13(46.42 \%)$ & \\
\hline \multicolumn{4}{|c|}{ Disease parameters at the time of study } \\
\hline anti $d s-D N A$ positivity & $38(59.37 \%)$ & $10(35.71 \%)$ & \\
\hline$C 3^{a^{b}}$ & $0.90 \pm 0.26$ & $0.95 \pm 0.29$ & \\
\hline$C 4^{a}{ }^{c}$ & $0.17 \pm 0.09$ & $0.19 \pm 0.10$ & \\
\hline SLEDAI index ${ }^{a}$ & $5.55 \pm 4.74$ & $13.3 \pm 9.16$ & \\
\hline High $>14$ & $8(12.5 \%)$ & $14(50.0 \%)$ & \\
\hline Low $<7$ & $41(64.06 \%)$ & $7(25.0 \%)$ & \\
\hline
\end{tabular}

a mean \pm standard deviation, ${ }^{b}$ normal value $0,90-1,80 \mathrm{~g} / \mathrm{l}, \mathrm{c}$ normal value $0,10-0,40 \mathrm{~g} / \mathrm{l}$ 


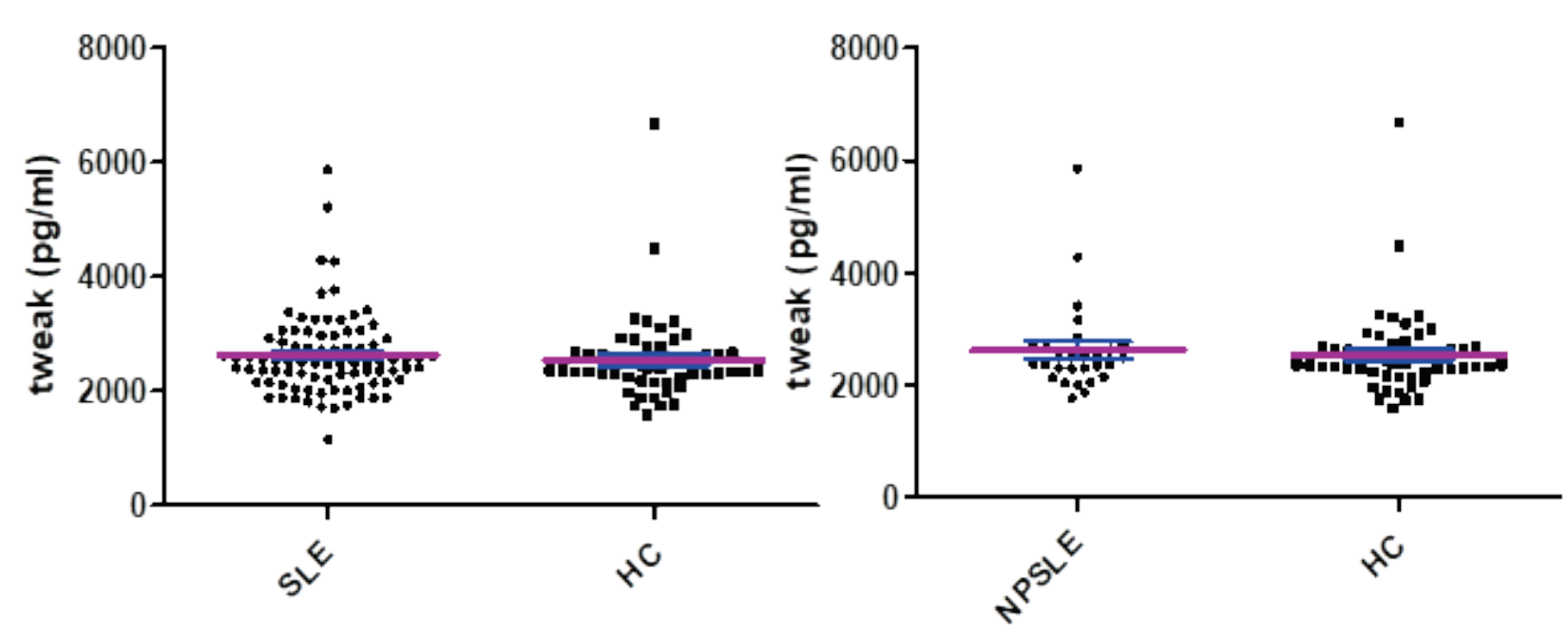

Fig. 1. Comparison of the serum TWEAK levels between SLE, NPSLE patients and healthy control group (HC)

Table 2. Comparison of the serum TWEAK levels of the most common NPSLE.

\begin{tabular}{lccccc}
\hline NPSLE syndrome & Headache & CVD $^{\mathbf{b}}$ & Seizures & CD $^{\mathbf{c}}$ & Anxiety \\
\hline positive & $18(64.28 \%)$ & $6(21.42 \%)$ & $12(42.85 \%)$ & $15(53.57 \%)$ & $14(50 \%)$ \\
TWEAK $^{a}$ & $2711( \pm 956.4)$ & $2253( \pm 338.9)$ & $2695( \pm 1027)$ & $2755( \pm 1025)$ & $2625( \pm 859.2)$ \\
p value (two-tailed) & 0.3081 & 0.2484 & 0.5922 & 0.5012 & 0.4871 \\
\hline
\end{tabular}

a - TWEAK serum level is reported as mean \pm standard deviation in $\mathrm{pg} / \mathrm{ml}, \mathrm{b}$ - Cerebrovascular disease c - Cognitive dysfunction. The patients might have had $>1$ manifestation

Additionally, the levels of serum TWEAK in NPSLE patients with and without the most common NPSLE syndromes (headache, seizures, cerebrovascular disease, cognitive dysfunction and anxiety) did not differ (Table 2), either. There was also no correlation between TWEAK serum levels and SLEDAI score in all SLE patients or in NPSLE patients (Table 3). Similarly, no difference of TWEAK level in NPSLE patients with high and low SLEDAI score was observed. Moreover, no patient had disruption of the blood-brain barrier evaluated by MRI.

Table 3. Correlation NPSLE TWEAK level with disease activity (SLEDAI index).

\begin{tabular}{|c|c|c|}
\hline & \multicolumn{2}{|c|}{ TWEAK $^{\mathrm{a}} 2425( \pm 810)$} \\
\hline SLEDAI index ${ }^{b} 13.3$ & $r$ & $\mathrm{P}$ \\
\hline$( \pm 9.16)$ & 0.2113 & 0.2805 \\
\hline
\end{tabular}

$r=$ correlation coefficient $p=p$ value (two tailed) $a-$ TWEAK serum level is reported as mean \pm standard deviation in $\mathrm{pg} / \mathrm{ml}$, $\mathrm{b}$ - mean \pm standard deviation

\section{Discussion}

SLE is a chronic autoimmune disease with multiorgan involvement. Although neuropsychiatric impairment is one of the most common manifestations of SLE, the mechanism of pathogenesis remains unclear and a specific biomarker for diagnosis is still missing. Few studies have shown a potential involvement of TWEAK in the pathogenesis of the disease $[30,32,40]$. It has been shown that urinary TWEAK is a useful biomarker in lupus nephritis and correlates with renal disease activity (El-Shehaby et al. 2011, Gao et al. 2009, Liu et al. 2011, Ruiz-Ortega et al. 2014, Schwartz et al. 2009, Schwartz et al. 2006, Xuejing et al. 2012). More recently TWEAK has become a point of interest in neuropsychiatric involvement.

In our study, we examined serum TWEAK levels in patients with SLE including NPSLE and healthy controls. We showed no significant differences in TWEAK levels among these groups. Our data support previous findings of comparable serum TWEAK levels in NPSLE and SLE patients and the non-autoimmune disease group (Fragoso-Loyo et al. 2016). However, in this study the authors did not compare the association of 
TWEAK with specific neuropsychiatric manifestations. Our study analyzed TWEAK levels in patients in the most common NPSLE syndromes but no associations were demonstrated, either.

However, there are few studies demonstrating elevated TWEAK serum levels in SLE patients compared to healthy controls (ElGendi and El-Sherif, 2009, Wang et al. 2012). In addition, serum TWEAK levels were also higher in SLE patients with vasculitis than those without vasculitis, and so were in the comparison between patients with and without headache. Additionally, Wang et al. (2012) examined the expression of TWEAK mRNA in peripheral blood mononuclear cells from patients with SLE and healthy controls, and they found the TWEAK mRNA expression decreased in SLE patients. In addition, El Gendi et al. described elevated TWEAK levels in SLE patients with lupus nephritis than in patients without renal involvement (ElGendi and El-Sherif 2009).

The study by Fragoso-Loyo et al. examined the levels of TWEAK in cerebrospinal fluid in NPSLE patients, non-NPSLE patients and controls, where TWEAK levels were only slightly elevated in SLE patients compared with non-autoimmune controls. There was no difference between SLE with and without NPSLE group. The major limitation of their study, despite the large number of patients with NPSLE, was the evaluation of the NPSLE group only as a whole with no regard to the particular clinical NPSLE form.

Another study failed to find any differences in TWEAK levels in the cerebrospinal fluid of multiple sclerosis patients versus patients with non-multiple sclerosis inflammatory diseases. However, these data indicated a potential role of TWEAK in inflammatory disorders, including NPSLE (Desplat-Jego et al. 2009).

In our study, we did not find any correlations between serum TWEAK levels and activity of the disease in the whole group as well as in the NPSLE subgroup. In NPSLE patients this might be due to the fact, that this was the prevalent study, where only a fraction of patients had acute problems. In acute patients the activity of the disease may be certainly high, but in our group there were mostly patients with chronic long-standing problems or neuropsychiatric manifestation in history, so the disease activity was not so high at the NPSLE group generally. Our data are in keeping with a lack of differences between active and inactive disease SLE patients demonstrated previously. Similarly, no correlations of serum TWEAK levels and the SLEDAI-2K score at the onset of neuropsychiatric manifestation were shown (Fragoso-Loyo et al. 2016).

It was demonstrated, that the major function of TWEAK is a modulation of blood-brain barrier permeability (Winkles 2008). However, none of the NPSLE patients in our study suffered from the bloodbrain barrier damage evaluated by MRI. This may also, at least, partially explain the lack of differences and associations demonstrated in our study.

The main limitation of our study is the small group of NPSLE patients and the use of serum samples only with no matching cerebrospinal fluid samples. The cytology analysis of cerebrospinal fluid as a basic neurological examination was not available as well.

Despite the fact that our study did not support the hypothesis of that TWEAK is involved in development of NPSLE, there exist data about TWEAK/Fn14 axis (Xu et al. 2016) and other findings (Desplat-Jego et al. 2009, ElGendi and El-Sherif 2009, Fragoso-Loyo et al. 2016, Wang et al. 2012) indicating its possible role in the pathogenesis of neuropsychiatric lupus. It seems to be ineffective to measure the serum levels of any biomarker of neuropsychiatric lupus as the levels in CSF are often completely different in majority of biomarkers tested in previous studies. As demonstrated for anti-NMDA antibodies, their correlation with NPSLE was observed in CSF only, not in serum (Arinuma et al. 2008). Similarly, levels of certain cytokines were also found to be elevated in NPSLE patients only in the CSF (Yoshio et al. 2016), TWEAK may be the same example. And as mentioned above, the presence of TWEAK in CSF might represent a potential discriminating marker for NPSLE but with low specificity. So there is still a need for more clinical trials and arguments, including paired (serum and CSF) samples in this issue which may be potential goal of our future studies.

\section{Conflict of Interest}

There is no conflict of interest.

\section{Acknowledgements}

The study was supported by the project of the Ministry of Health of Czech Republic for conceptual development of research organization 00023728 . 


\section{References}

The American College of Rheumatology nomenclature and case definitions for neuropsychiatric lupus syndromes. Arthritis Rheum 42: 599-608, 1999. https://doi.org/10.1002/1529-0131(199904)42:4<599::AIDANR2>3.0.CO;2-F

ARINUMA Y, YANAGIDA T, HIROHATA S: Association of cerebrospinal fluid anti-NR2 glutamate receptor antibodies with diffuse neuropsychiatric systemic lupus erythematosus. Arthritis Rheum 58: 1130-1135, 2008. https://doi.org/10.1002/art.23399

BELMONT HM, ABRAMSON SB, LIE JT: Pathology and pathogenesis of vascular injury in systemic lupus erythematosus. Interactions of inflammatory cells and activated endothelium. Arthritis Rheum 39: 9-22, 1996. https://doi.org/10.1002/art.1780390103

BERTIN D, STEPHAN D, KHRESTCHATISKY M, DESPLAT-JEGO S: Is TWEAK a biomarker for autoimmune/chronic inflammatory diseases? Front Immunol 4: 489, 2013. https://doi.org/10.3389/fimmu.2013.00489

BORTOLUZZI A, SCIRE CA, BOMBARDIERI S, CANIATTI L, CONTI F, DE VITA S, DORIA A, FERRACCIOLI G, GREMESE E, MANSUTTI E, MATHIEU A, MOSCA M, PADOVAN M, PIGA M, TINCANI A, TOLA MR, TOMIETTO P, VALESINI G, ZEN M, GOVONI M: Development and validation of a new algorithm for attribution of neuropsychiatric events in systemic lupus erythematosus. Rheumatology (Oxford) 54: 891-898, 2015. https://doi.org/10.1093/rheumatology/keu384

BRIANI C, LUCCHETTA M, GHIRARDELLO A, TOFFANIN E, ZAMPIERI S, RUGGERO S, SCARLATO M, QUATTRINI A, BASSI N, ERMANI N, BATTISTIN L, DORIA A: Neurolupus is associated with antiribosomal $\mathrm{P}$ protein antibodies: an inception cohort study. J Autoimmun 32: 79-84, 2009. https://doi.org/10.1016/j.jaut.2008.12.002

DESDPLAT-JEGO S, FEUILLET L, CREIDY R, MALIKOVA I, RANCE R, KHRESTCHATISKY M, HAHMK, BURKLY LC, PELLETIER J, BOUCRAUT J: TWEAK is expressed at the cell surface of monocytes during multiple sclerosis. J Leukoc Biol 85: 132-135, 2009. https://doi.org/10.1189/jlb.0608347

EL-SHEHABY A, DARWEESH H, EL-KHATIB M, MOMTAZ M, MARZOUK S, EL-SHAARAWY N, EMAD Y: Correlations of urinary biomarkers, TNF-like weak inducer of apoptosis (TWEAK), osteoprotegerin (OPG), monocyte chemoattractant protein-1 (MCP-1), and IL-8 with lupus nephritis. J Clin Immunol 31: 848-856, 2011. https://doi.org/10.1007/s10875-011-9555-1

EL-GENDI SS, EL-SHERIF WT: Anti-C1q antibodies, sCD40L, TWEAK and CD4/CD8 ratio in systemic lupus erythematosus and their relations to disease activity and renal involvement. Egypt J Immunol 16: 135-148, 2009.

FONT J, CERVERA R: 1982 revised criteria for classification of systemic lupus erythematosus--ten years later. Lupus 2: 339-341, 1993. https://doi.org/10.1177/096120339300200512

FRAGOSO-LOYO H, ATISHA-FREGOSO Y, NUNEZ-ALVAREZ CA, LLORENTE L: Utility of TWEAK to assess neuropsychiatric disease activity in systemic lupus erhytematosus. Lupus 25: 364-369, 2016. https://doi.org/10.1177/0961203315610206

FRIERI M: Mechanisms of disease for the clinician: systemic lupus erythematosus. Ann Allergy Asthma Immunol 110: 228-232, 2013. https://doi.org/10.1016/j.anai.2012.12.010

GAO HX, CAMPBELL SR, BURKLY LC, JAKUBOWSKI A, JARCHUM I, BANAS B, SALEEM MA, MATHIESON PW, BERMAN JW, MICHALESON JS, PUTTERMAN C: TNF-like weak inducer of apoptosis (TWEAK) induces inflammatory and proliferative effects in human kidney cells. Cytokine 46: 24-35, 2009. https://doi.org/10.1016/j.cyto.2008.12.001

HANLY JG: Diagnosis and management of neuropsychiatric SLE. Nat Rev Rheumatol 10: 338-347, 2014. https://doi.org/10.1038/nrrheum.2014.15

HANLY JG, MC CURDY G, FOUGERE L, DOUGLASJA, THOMPSON K: Neuropsychiatric events in systemic lupus erythematosus: attribution and clinical significance. J Rheumatol 31: 2156-2162, 2004. 
HANLY JG, UROWITZ MB, SU L, BAE SC, GORDON C, WALLACE DJ, CLARKE A, BERTNATSKY S, ISENBERD D, RAHMAN A, ALACRON GS, GLADMAN DD, FORTIN PR, SANCHZ-GUERRERO J, ROMERO-DIAR J, MERRIL JT, GINZLER E, BRUCE IN, STEINSSON K, KHAMASHTA M, PETRI M, MANZI S, DOOLEY MA, RAMSEY-GOLDMAN R, VAN VOLLENHOVEN R, NIVED O, STURFELT G, ARANOW C, KALUNIAN K, RAMON-CASALS M, ZOMA A, DOUGLAS J, THOMSON K, FAREWELL $\mathrm{V}$ : Prospective analysis of neuropsychiatric events in an international disease inception cohort of patients with systemic lupus erythematosus. Ann Rheum Dis 69: 529-535, 2010. https://doi.org/10.1002/art.22305

ISSHI K, HIROHATA S: Differential roles of the anti-ribosomal P antibody and antineuronal antibody in the pathogenesis of central nervous system involvement in systemic lupus erythematosus. Arthritis Rheum 41: 1819-1827, 1998. https://doi.org/10.1002/1529-0131(199810)41:10<1819::aid-art14>3.0.co,2-y

JEONG HW, HER M., BAE JS, KIM SK, LEE SW, KIM HK, KIM D, PARK N, CHUNG WT, LEE SY, CHOE JY, KIM IJ: Brain MRI in neuropsychiatric lupus: associations with the 1999 ACR case definitions. Rheumatol Int 35: 861-869, 2015. https://doi.org/10.1007/s00296-014-3150-8

JOSEPH FG, SCOLDING NJ: Neurolupus. Pract Neurol 10: 4-15, 2010.

KANG EH, SHEN GQ, MORRIS R, METZGER A, LEE EY, LEE YJ, LEE EB, SONG YW: Flow cytometric assessment of anti-neuronal antibodies in central nervous system involvement of systemic lupus erythematosus and other autoimmune diseases. Lupus 17: 21-25, 2008. https://doi.org/10.1177/0961203307085256

KASAMA T, MAEOKA A, OGURO N: Clinical features of neuropsychiatric syndromes in systemic lupus erythematosus and other connective tissue diseases. Clin Med Insights Arthritis Musculoskelet Disord 9: 1-8, 2016. https://doi.org/10.4137/cmamd.s37477

KOZORA E, HANLY JG, LAPTEVA L, FILLEY CM: Cognitive dysfunction in systemic lupus erythematosus: past, present, and future. Arthritis Rheum 58: 3286-3298, 2008. https://doi.org/10.1002/art.23991

LIU ZC, ZHOU QL, LI XZ, YANG JH, AO X, VEERARAGOO P, ZUO XX: Elevation of human tumor necrosis factor-like weak inducer of apoptosis in peripheral blood mononuclear cells is correlated with disease activity and lupus nephritis in patients with systemic lupus erythematosus. Cytokine 53: 295-300, 2011. https://doi.org/10.1016/j.cyto.2010.11.012

MAGRO-CHECA C, ZIRKZEE EJ, HUIZINGA TW, STEUP-BEEKMAN GM: Management of neuropsychiatric systemic lupus erythematosus: current approaches and future perspectives. Drugs 76: 459-483, 2016. https://doi.org/10.1007/s40265-015-0534-3

MENNON S, JAMESON-SHORTALL E, NEWMAN SP, HALL-CRAGGS MR, CHINN R, ISENBERG DA: A longitudinal study of anticardiolipin antibody levels and cognitive functioning in systemic lupus erythematosus. Arthritis Rheum 42: 735-741, 1999. https://doi.org/10.1002/1529-0131(199904)42:4<735::aidanr17>3.0.co, 2-1

OGAWA E, NAGAI T, SAKUMA Y, ARINUMA Y, HIROHATA S: Association of antibodies to the NR1 subunit of N-methyl-D-aspartate receptors with neuropsychiatric systemic lupus erythematosus. Mod Rheumatol 26: 377-383, 2016. https://doi.org/10.3109/14397595.2015.1083163

PAMFIL C, FANOURIAKIS A, DAMIAN L., RINZIS M, SIDIROPOULOS P, TSIVGOULIS G, REDNIC C, BERTSIAS G, BOUMPAS DT: EULAR recommendations for neuropsychiatric systemic lupus erythematosus vs usual care: results from two European centres. Rheumatology (Oxford) 54: 1270-1278, 2015. https://doi.org/10.1093/rheumatology/keu482

PERRICONE C, PENDOLINO M, OLIVIERI M, CONTI F, VALESINI G, AALESSANDRI: Neuropsychiatric manifestations associated with anti-endothelial cell antibodies in systemic lupus erythematosus. Isr Med Assoc J 17: 171-178, 2015.

POLAVARAPU R, GONGORA MC, WINKLES JA, YEPES M: Tumor necrosis factor-like weak inducer of apoptosis increases the permeability of the neurovascular unit through nuclear factor-kappa B pathway activation. J Neurosci 25: 10094-10100, 2005. https://doi.org/10.1523/jneurosci.3382-05.2005

POPESCU A, KAO AH: Neuropsychiatric systemic lupus erythematosus. Curr Neuropharmacol 9: 449-457, 2011. https://doi.org/10.2174/157015911796557984 
RUIZ-ORTEGA M, ORTIZ A, RAMOS AM: Tumor necrosis factor-like weak inducer of apoptosis (TWEAK) and kidney disease. Curr Opin Nephrol Hypertens 23: 93-100, 2014. https://doi.org/10.1097/01.mnh.0000437331.23794.81

SARBU N, ALOBEIDI F, TOLEDANO P, ESPINOSA G, GILES I, RAHMAN A, YOUSRY T, CAPURRO S, JAGER R, CERVERA R, BARGALLO N: Brain abnormalities in newly diagnosed neuropsychiatric lupus: systematic MRI approach and correlation with clinical and laboratory data in a large multicenter cohort. Autoimmun Rev 14: 153-159, 2015. https://doi.org/10.1016/j.autrev.2014.11.001

SCHWARTZ N, RUBINSTEIN T, BURKLY LC, COLLINS CE, BLANCO I, SU L, HOJAILI B, MACKAY M, ARANOW C, STOHL W, ROVIN BH, MICHAELSON JS, PUTTERMAN C: Urinary TWEAK as a biomarker of lupus nephritis: a multicenter cohort study. Arthritis Res Ther 11: R143, 2009. https://doi.org/10.1186/ar2816

SCHWARTZ N, SU L, BURKLY LC, MACKAY M, ARANOW C, KOLLAROS M, MICHAELSON JS, ROVIN BHPUTTERMAN C: Urinary TWEAK and the activity of lupus nephritis. J Autoimmun 27: 242-250, 2006. https://doi.org/10.1016/j.jaut.2006.12.003

SIBBIT WL JR, BRANDT JR, JOHNSON CR, MALDONADO ME,PATEL SR, FORD CC, BANKHURST AD, BROOKS WM: The incidence and prevalence of neuropsychiatric syndromes in pediatric onset systemic lupus erythematosus. J Rheumatol 29: 1536-1542, 2002.

WANG C, CHEN LL, PAN HF, LENG RX, QIN WT, YE DQ: Expression of human tumor necrosis factor-like weak inducer of apoptosis in patients with systemic lupus erythematosus. Clin Rheumatol 31: 335-339, 2012. https://doi.org/10.1007/s10067-011-1865-4

WEN J, DOERNER J, WEIDENHEIM K., XIA Y, STOCK A, MICHAELSON JS, BURKLY LC, GULINELLO M, PUTTERMAN C: TNF-like weak inducer of apoptosis promotes blood brain barrier disruption and increases neuronal cell death in MRL/lpr mice. J Autoimmun 60: 40-50, 2015. https://doi.org/10.1016/j.jaut.2015.03.005

WEN J, XIA Y, STOCK A, MICHAELSON JS, BURKLY LC, GULINELLO M, PUTTERMAN C: Neuropsychiatric disease in murine lupus is dependent on the TWEAK/Fn14 pathway. J Autoimmun 43: 44-54, 2013. https://doi.org/10.1016/j.jaut.2013.03.002

WILSON HA, WINFIELD JB, LAHITA RG, KOFFLER D: Association of IgG anti-brain antibodies with central nervous system dysfunction in systemic lupus erythematosus. Arthritis Rheum 22: 458-462, 1979. https://doi.org/10.1002/art.1780220504

WINKLES JA: The TWEAK-Fn14 cytokine-receptor axis: discovery, biology and therapeutic targeting. Nat Rev Drug Discov 7: 411-425, 2008. https://doi.org/10.1038/nrd2488

XU WD, ZHAO Y, LIU Y: Role of the TWEAK/Fn14 pathway in autoimmune diseases. Immunol Res 64: 44-50, 2016. https://doi.org/10.1007/s12026-015-8761-y

XUEJING Z, JIAZHEN T, JUN L, XIANGQING X, SHUGUANG Y, FUYOU L: Urinary TWEAK level as a marker of lupus nephritis activity in 46 cases. J Biomed Biotechnol 359647, 2012. https://doi.org/10.1155/2012/359647

YAZDANY J: Health-related quality of life measurement in adult systemic lupus erythematosus: Lupus quality of life (LupusQoL), Systemic lupus erythematosus-specific quality of life questionnaire (SLEQOL), and Systemic lupus erythematosus quality of life Questionnaire (L-QoL). Arthritis Care Res (Hoboken) 63 (Suppl 11): S413-419, 2011. https://doi.org/10.1002/acr.20636

YOSHIO T, OKAMOTO H, KURASAWA K, DEI Y, HIROHATA S, MINOTA S: IL-6, IL-8, IP-10, MCP-1 and G-CSF are significantly increased in cerebrospinal fluid but not in sera of patients with central neuropsychiatric lupus erythematosus. Lupus 25: 997-1003, 2016. https://doi.org/10.1177/0961203316629556

ZIRKZEE EJ, STEUP-BEEKMAN GM, VAN DER MAST RC, BOLLEM EL, VAN DER WEE NL, BAPTIST E, SLEE TM, HUISMAN MV, MIDDELKOOP HA, LUYENDIJK J, VAN BUCHEM MA, HUIZINGA TW: Prospective study of clinical phenotypes in neuropsychiatric systemic lupus erythematosus, multidisciplinary approach to diagnosis and therapy. J Rheumatol 39: 2118-2126, 2012. https://doi.org/10.3899/jrheum.120545 